\title{
Students' Attitude and Financial Behaviour among Malaysian Youth: Preliminary Insight
}

\author{
Mohamad Hafiz bin Rosli ${ }^{1}$ \\ ${ }^{1}$ Faculty of Business and Accountancy, Universiti Selangor, Malaysia,
}

\begin{abstract}
This study aims to discover the spending type of Malaysian youth and does they have saving attitude. This research utilized survey questionnaires for data collection and a total of 238 respondents were taken into this study. The collected data were analyzed by using Statistical Package for Social Science (SPSS) version 20.0. The data were summarized using descriptive statistics. The results showed that most of the respondents having good students attitude and financial Behaviour. This study contributes to further understanding of financial behavior and student attitude among Malaysian youth.
\end{abstract}

Key words: Students'Attitude, Financial Behaviour

\section{INTRODUCTION}

Bankruptcy has been viewed as the more serious matter that now becoming trend among Malaysian youth. [1] reported that 11 youth going bankrupt each day because of their poor financial management giving impact to 22,663 Malaysians under the age of 35 being declared bankrupt between 2011 and September 2015. Malaysian Financial Planning Council (MFPC) revealed that this group of people fails to manage their financial resources and do not understand the importance of proper financial planning. Furthermore, [2] reported that 3,450 of youths age between 20-30 years seeking assistance from Malaysia Credit Counseling and Debt Management Agency's (AKPK) in 2016. More seriously, from 2013 to August 2017 , the courts have cleared 1,356 cases while another 11,627 cases have been terminated upon annulment of the bankruptcy order and a total of 44,950 cases were discharged via Insolvency Certificate. Therefore, this study aims to discover the spending type of Malaysian youth and does they have saving attitude.

\section{LITERATURE REVIEWS}

Financial literacy associates to the ability of knowing and understanding financial concepts and matters [3]. It has been viewed as an important factor in determining financial behaviour [4]. Delafrooz and Laily [5] have conducted a study in Malaysia to examine the degree to which financial literacy influenced the saving behaviour. The finding showed that saving behaviour is significantly influenced by the financial literacy whereby individuals with low level of financial literacy are not intended to save and eventually encounter financial problems in future. Albeerdy and Gharleghi [6] on their study at several colleges and universities in Malaysia have found that education, financial socialization agents and money attitude have a direct influence to financial literacy.

Student's attitude can be defined as a student with their financial attitudes and habits towards money, spending and saving practices [7]. Lim, Sia, and Gan [8] indicated that there is a significant impact of self-attitude on saving behaviour. However, Tuvesson and $\mathrm{Yu}$ [9] reported that female students tend to have more positive attitude and motivated towards saving than male students. Attitude and preference are determined as a significant component of financial behaviour [10]. Dahlia, Rabitah and Zuraidah [11] conducted a research among undergraduates students found that students with higher financial attitude had a higher level

Corresponding Author: Mohamad Hafiz bin Rosli, Faculty of Business and Accountancy, Universiti Selangor, Malaysia, mohd_hafiz@unisel.edu.my 
of financial literacy. Thapa and Nepal [12] found that financial awareness and financial attitude are positively correlated. It means youngsters in university are more knowledgeable to deal with monetary affairs if they have good and positive financial attitude. Albeerdy and Gharleghi [6], the researchers found that there was a significant positive relationship between financial awareness and financial attitude among youths in university. Siew. Raza [13] defined financial behaviour expands the domain of finance beyond portfolios, asset pricing, and market efficiency.

\section{METHODOLOGY}

This preliminary study is conducted using quantitative approach. The sample of this study focuses on Malaysian youth in Klang Valley that is currently undergoing tertiary education whether at diploma or bachelor degree program. 300 questionnaires were sent and 250 responses received. However, only 238 responses were valid after deducting incomplete responses. A survey questionnaire consists of demographic part and variable tested. Respondents are required to indicate their responses based on a five point Likert scale $(1=$ strongly disagree, $2=$ Disagree, 3 $=$ Neutral, $4=$ Agree, $5=$ strongly agree) .

\section{RESULT ANALYSES AND DISCUSSIONS}

\section{Respondent Background}

Table 1. Respondent background

\begin{tabular}{lrc}
\hline & Frequency & Percent \\
\hline Gender & & \\
\hline Male & 63 & 26.5 \\
Female & 175 & 73.5 \\
\hline Age & & \\
\hline $18-19$ & 26 & 10.9 \\
20 - 21 & 41 & 17.2 \\
22 - 23 & 108 & 45.4 \\
24 and above & 63 & 26.5 \\
\hline Academic Programme & & \\
\hline Diploma & 69 & 29.0 \\
Bachelor & 169 & 71.0 \\
\hline Monthly spending & & \\
\hline RM0 - RM200 & 40 & 16.8 \\
RM201 - RM500 & 101 & 42.4 \\
RM501 - RM800 & 46 & 19.3 \\
RM801 - RM1,000 & 26 & 10.9 \\
RM1,000 and above & 25 & 10.5
\end{tabular}

Table 1 presents the demographic data of the respondent consist of composition between $74 \%$ of female and $27 \%$ is male with most of the respondents age is between 22 to 23 years. $71.0 \%$ of respondents currently pursing bachelor degree programs. More than $42.4 \%$ respondents have spent around RM201 RM500 per month. Personal expenses such as clothing, shoes, food and others approximately to $79.3 \%$ and there is only $10.4 \%$ goes to saving.

\section{Financial Behaviour}

Most of the respondent agreed that the financial behaviour is important based on the reported mean score. The highest mean score of 4.0168 (standard deviation $=0.80067$ ) indicates that ' $I$ save to achieve certain goals'. 183 respondents contributes to $76.9 \%$ agreed that they have to save to achieve certain goals. On top of that, 167 respondents contributes to $70.2 \%$ agreed 
that they have set aside money for their wants (e.g: travelling). Moreover, 164 respondents contributes to $68.9 \%$ agreed that they always have money available in the event of emergency. However, 23 respondents contribute $9.6 \%$ indicate that they did not record their daily expenses such as preparing some amount of money for specific purposes saving and entertainment.

\section{Student Attitude}

Most of the respondent agreed that the student's attitude is important based on the reported mean score. The highest mean score of 4.2731 (standard deviation $=0.89360$ ) indicates that ' $I$ acknowledge that saving is must'. On the other hand, 203 respondents contributes to $85.3 \%$ agreed that they have acknowledge that saving is must. Next, 179 respondents contributes to $75.2 \%$ agreed that they have save some of their money. Furthermore, 113 respondents contributes to $47.5 \%$ agreed that they set saving goals for their self, they rarely achieve them. However, 135 respondents contribute 56.7\% indicate that they don't save, because they think it's too hard.

\section{CONCLUSIONS}

The finding of this study indicates that Malaysian youth that currently undergoing study in higher learning institutions having a positive financial behavior and student attitude. Eventhough, they realized the importance of saving through the responses of financial behaviour and student behaviour, the types of spending still not favor to saving. Therefore future research could investigate whether there is a relationship between student's attitude and financial behaviour. Based on this study, the responses of financial behaviour, doesn't portray the news reported in the media. Hence, it leave a gap whether Malaysian youth do have a good saving attitude but doent apply in their daily life. Future research also needs to expand the respondents and include various method of data collection such as interview. This study contributes to further understanding of financial behavior and student attitude among Malaysian youth.

\section{REFERENCES}

[1] Eleven youths going bankrupt each day (2016, October 8). The Malay Mail Online. Retrieved from: http://m.themalaymailonline.com/mala ysia/article/11-youths-going-bankrupteach-day

[2] Three thousand four hundreds youth sought financial help in first 8 months. (2017, October 3). The Sun Daily. Retrieved from: http://www.thesundaily.my/news/2017 /10/03/3400-youths-sought-financialhelp-first-8-months

[3] Remund, D.L., 2010. Financial literacy explicated: The case for a clearer definition in an increasingly complex economy. Journal of Consumer Affairs, 44(2), pp.276-295.

[4] Klapper, L.F., Lusardi, A. \& Panos, G.A., 2012. Financial literacy and the financial crisis,

[5] Delafrooz, N. \& Laily (2011). Determinants of saving behavior and financial problem among employees in Malaysia. Australian Journal of Basic and Applied Sciences, 5(7), 222-228, 2011 ISSN 1991-8178.

[6] Albeerdy, M. I., \& Gharleghi, B. (2015). Determinants of the financial literacy among college students in Malaysia. International Journal of Business Administration, 6(3), 15-24. Doi:10.5430/ijba.v6n3p15

[7] Burgess, S. M. (2005). The importance and motivational content of money attitudes: South Africans with living standards similar to those in industrialized Western countries. South African Journal of Psychology.

[8] Lim, C.S., Sia, B.K., \& Gan, G.J. (2011). The analysis of psychological factors affecting savers in Malaysia. Middle Easter Finance and Economic, 12, 77-85.

[9] J. Tuvesson and S. Yu, Student saving, does it exist? A study of students' saving behavior, attitude towards saving and motivation to save., Umeå School of Business, Umeå University, 2011.

[10] Atkinson, A., \& Messy, F. A. (2012). Measuring financial literacy. (OECD 
Working Paper No.15). OECD Publishing.

[11] Dahlia Ibrahim, Rabitah Harun and Zuraidah Mohamed Isa. (2009). A Study on Financial Literacy of Malaysian Degree Students. Canadian Academy of Oriental and Occidental Culture. Vol.5 No.4 2009.

[12] Thapa, B. S., \& Nepal, S. R. (2015). Financial Literacy in Nepal: A Survey
Analysis from College Students. 2nd International Conference on Economics and Finance. Kathmandu, Nepal.

[13] Raza, A. (2014). Review of behavioral finance as an emerging field of investment decision making. IOSR Journal of Business and Management, 16(6),156-172 